\title{
FETISHIZED READING AND WRITING IN THE ENGLISH PATIENT AND ATONEMENT FILM ADAPTATIONS
}

Cynthia Beatrice Costa ${ }^{1^{*}}$

${ }^{1}$ Universidade Federal de Uberlândia, Uberlândia, MG, Brasil

\begin{abstract}
Reading and writing-related objects, whether in the form of books, letters, or typewriters, are central elements in the films The English Patient, by Anthony Minghella (1996), and Atonement, by Joe Wright (2007), both adapted from novels. By drawing similarities between these two adaptations (Hutcheon 2013; Elleström 2017), the present text illustrates how written words and writing-related objects can be cinematically fetishized (Apter 1991; Mulvey 1996). It also suggests why, despite being capable of existing as autonomous creations, both films proudly maintain a tight connection with their source novels, thus standing as purposeful doubles.

Keywords: Film Adaptation; Writing Fetish; The English Patient; Atonement
\end{abstract}

\footnotetext{
*Translation assistant professor at Universidade Federal de Uberlândia (UFU). She holds a PhD in Translation Studies from Universidade Federal de Santa Catarina (UFSC). Her current post-doctoral research, under the supervision of Prof. Lenita Rimoli Pisetta at Universidade de São Paulo (USP), comprises the use of voice-over in literary film adaptations. She is a permanent member of the Graduate Program in Literary Studies at UFU and of the Postgraduate Translation Studies Program at UFSC. E-mail: cynthia.costa@ufu.br. ORCID: http:// orcid.org/0000-0002-3063-0121.
} 
"Words, Caravaggio. They have a power." Almásy (Ondaatje 2004, 249)

Written words, pages being turned, and letters read in voiceover (Kozloff 1988 , 3), among many other devices so often used on screen, can be a reminder that films frequently rely on literature to tell stories. The warm - sometimes enthusiastic - reception of The English Patient ${ }^{1}$ (1996), directed by Anthony Minghella, and Atonement ${ }^{2}$ (2007), directed by Joe Wright, may attest that the use of the written word in cinematic craft points to a desirable bond between film and source novel. Both are considered dual media successes (see Geraghty 2012, 359) and part of the select group of adaptations which seem to have achieved as much respect as artistic works as the novels on which they are based. As declared adaptations, which are understood here as "inherently 'palimpsestuous' works" (Hutcheon 2013,2) that guard their own characteristics as cinema (Elleström 2017, 522-523), both films abound with reading and writing-related elements that were mostly present in the novels, but that gain more of a fetishistic dimension when explored by the camera and exposed to our gaze.

The English Patient is an adaptation of Michael Ondaatje's Booker Prize winning novel (1992). It won nine Academy Awards, including Best Picture, and was then "celebrated as the most successful British film in Oscar history" (Laing 2007, 51), receiving "a critical response that ranged from the reverent to the positively ecstatic" (Thomas 2000, 197). Its success in retelling Ondaatje's novel is generally admired: "The novel is so labyrinthine that it's a miracle it was filmed at all, and the writer-director, Anthony Minghella, has done a creative job of finding visual ways to show how the rich language slowly unveils layers of the past" (Ebert 1996, para. 11). Cahir $(2006,130)$ writes that "each [novel and film] utilizes the specific tools of its medium to create equally memorable, rhapsodic and compassionate disquietudes on love in the time of war". At the other end of the spectrum, there has been some negativity, though. The English Patient has sometimes been criticized for being much too cold/slow/elaborate for the screen, being judged as "a crashing bore" (Simon 1996, para. 3) or "a swank literary Casablanca" (Gleiberman 1996, para. 2), leading to a "remote and, at times, faintly oppressive experience" (para. 4).

Atonement, adapted to the screen by Christopher Hampton, also secured multiple Academy Awards nominations, crowning its positive critical and commercial reception, and reviving the popularity of Ian McEwan's National Book Critics Award for Fiction winning novel: "Rarely has a book sprung so vividly to life, but also worked so enthrallingly in pure movie terms, as with Atonement, Brit helmer Joe Wright's smart, dazzlingly upholstered adaptation of Ian McEwan's celebrated 2001 novel" (Elley 2007, para. 1). Considered by some "the greatest living English novelist" (Bradshaw 2007, para. 2), McEwan was involved in the film as an executive producer, which may have helped it commercially. "The tiein between book and film was clearly made when the paperback version with the stars of the film on the cover was issued in August 2007" (Geraghty 359). 
Believing that in both cases the novel/film relationship has already been largely explored (see Thomas; Cahir; Geraghty; Hutcheon), the present text does not focus on a detailed comparison of source materials and their adaptations. Instead, it examines a common aspect of these two films: the fetishizing of the acts of writing and reading, and of all things related to them, through various cinematic devices. "Fetish", here, is inspired by a passage of the novel Atonement, in which the character Robbie Turner smells a book:

Willing himself not to, he raised the book to his nostrils and inhaled. Dust, old paper, the scent of soap on his hands, but nothing of her. How had it crept up on him, this advanced stage of fetishizing the love object? Surely Freud had something to say about that in Three Essays on Sexuality. (McEwan 2002, 79)

Freud theorizes the subject in the essay "Fetishism", published in 1927, suggesting fetish as a substitute for the maternal phallus "that had been extremely important in early childhood but was afterwards lost" - thus, the purpose of the fetish would be "to preserve it from being lost" (Freud 1997, 205). But it is not on such literal Freudian terms that the concept of "fetish" is adopted here, even though the discussion still relies on psychoanalytic-oriented propositions by Apter and Mulvey, who have applied their views to literature and cinema. After all, "it's very well known that the fetish very often attracts the gaze" (Mulvey 1996, 6 ), and films are primarily visual.

Mulvey explains that the Freudian fetish is "constructed from an excessive, phantasmatic inscription: that is, the setting up of a sign, which is of value only to its worshippers, to conceal a lack, to function as a substitute for something perceived as missing" (Mulvey 1993, 8). Fetish would be a "surrogate object of desire" (Apter 1991, 4), an object worshiped because it replaces something else much more significant. In films, such objects frequently work as "stand ins" for something so obsessively desirable that they provoke a frenzy in the characters who search, see, and/or touch them, even driving their actions (see Moses 2004).

A powerful Herodotus book, around which all relationships are built, seems almost omnipresent in The English Patient; in Atonement, a typed note changes the characters' fate. The camera often values, even sensualizes, these elements, as it will be discussed in what follows; first in two separate commentaries on each film, and afterwards approaching both in association to one other.

\section{The English Patient and the book fetish}

A partial continuation of Ondaatje's previous novel In the Skin of a Lion (1987), The English Patient follows several points of view and multiple plots. One focuses on the French-Canadian nurse Hana, who is taking care of a patient in an abandoned Tuscan villa at the end of the Second World War. Another one is the love affair the patient had while working as a cartographer in North Africa just before the war's outbreak. The patient is actually not English, as the title suggests, 
but Hungarian, and his name is Count Ladislaus de Almásy. ${ }^{3}$ His body was burnt beyond recognition and he seems to suffer from amnesia, which results in an "obliteration" of his identity (Wooton 2016, 167).

Almásy is a man whose life is "governed by words" (Ondaatje 2004, 245). His affair with Katherine, who is married to his co-worker Clifton, begins because of a book he carries everywhere with him: The Histories, by Herodotus. This is important to the understanding of the story, posing "the distinctively postmodern question about how history is related to fiction, and the difficulty of distinguishing between fact and fiction" (Bolland 2002, 49), which mirrors the web of memories and different points of view in Almásy's story.

Minghella's film recreates the non-linear narrative of Ondaatje's novel, moving back and forward in time and shifting points of view. The love of words is notoriously emphasized throughout its two hours and forty-two minutes running time. It opens with the close-up shooting of a paintbrush drawing a figure on parchment, while Hungarian folk vocalist Márta Sebestyén sings "Szerelem, Szerelem" ("Love, Love") in the background. Such images of drawings, paintings, and handwriting seem to adapt onto the screen the sensuality expressed with words in the novel: "Remove the politics, and it is the loveliest phrase I know. Lybia. A sexual, drawn-out word, a coaxed well", describes Almásy (Ondaatje 273). The line is absent from Minghella's screenplay, but the film does find other ways to express the same sort of suggestiveness.

Cahir (135) considers Minghella's adaptation a "traditional translation," because it maintains "the overall traits of the novel" - plot, settings, themes, and stylistic conventions, even though it does overvalue Katharine and Almásy's love story. It is possible to argue, however, that the novel is much more fragmentary and slippery than the film, requiring constant inference from the reader. Somewhat heroic and romanticized on screen (Laing 54), Almásy is also more of a disjointed character in the novel, which "continually diverts attention away from the selfabsorbed stories [he tells]", an example of "Ondaatje's postmodern resistance to dominant narratives" (Wootton 172).

Near the end of the novel, Almázy recounts how Katherine read a passage of his book in an evening in the desert: "This is the story of how I fell in love with a woman, who read me a specific story of Herodotus. I heard the words she spoke across the fire, never looking up, even she teased her husband. Perhaps she was just reading it to him" (Ondaatje 247). In the film, this happens earlier, in the first half-hour, and it represents a starting point in their relationship. Katherine (Kristin Scott-Thomas) tells by heart, to the men around the fire, Herodotus' insinuating tale of Gyges and the married queen he sees naked (27:46). As it will take Katherine some time still to have actual access to the book carried by Almásy (Ralph Fiennes), this implies that she read the tale before, in another copy of Herodotus. She is curious about Almásy's book anyway, because it is not the Herodotus in it that interests her, but the other contents he places between the pages. Herodotus is not the only author of the book: Almásy is a co-author of sorts. He even calls it a "scrapbook" (57:11). 
Especially to "co-author" Almásy and to Katherine, the book seems to be "invested with private magical or sexual significance", as Mulvey $(1996,122)$ elucidates while analyzing fetish in the context of Senegalese film Xala (1975), by Ousmane Sembène. She also states: "The fetishist overrates his object, and ignoring the commonsense value attributed to it by society, secretly attaches mysterious powers to it" (Mulvey 1996, 122). Almázy and Katherine are the fetishists in this case, and Amásy's book is fetishized as a substitute to a more direct communication between the lovers. Katherine asks to include her paintings in the collection he keeps inside the book. He first refuses, but later accepts, saying it would be an "honor" to have them (1:03:10). When she finally finds the opportunity to look at the contents of the book with great interest, she discovers notes talking about " $K$ ", who she correctly believes to be her. As she observes his scribblings, we, viewers, try and read them with her. The camera frames them close and long enough so we can decipher his musings at the same time that she does (1:04:57).

Almásy and Katherine's connection through writing is not only intellectual, but emotional and sensorial. When they say goodbye at the hotel door, before starting the actual affair, Almásy asks her to return his book, which she was now carrying in her backpack (1:10:54). The gesture is provocative, as if he was asking her to retrieve a part of him. Later, Katherine also confesses that one of the things she loves in life is Almásy's handwriting (1:14:50). After a temporary breakup, he tells her: "I've been trying to write with your taste in my mouth" (1:18:08).

The film shows images of Almázy writing, in the past, and through skilled editing the sequence transitions to the film's "present time", when his nurse Hana (Juliette Binoche) reads his musings aloud. She is charmed by some of his remarks, like "The heart is an organ of fire" (1:24:30). The presence of the book between them is important as a connection to the pre-war world, and to Almásy's identity. Caravaggio (Willem Dafoe), another resident of the Tuscan villa, also pays attention to Almásy's book - he recognizes him because of it. He says that, when Almásy was rescued, he had only one thing to his possession, "a copy of Herodotus filled with letters and cuttings", and then: "I saw you writing in that book at the embassy in Cairo" (2:04:41). The scene of Almásy's rescue is portrayed early in the film (05:33), when men in traditional Arabian headdresses open his book and look at the contents. One might wonder how such a voluminous book survived a plane crash and a fire, but the issue is not addressed - the fact only enhances the "kind of collective fantasy" (Mulvey 1996, 122) shared by the group of characters who overvalue the book's attribute of holding secrets of the past that somehow impact all their lives.

The fact that there seems to be thousands of books in the villa where they are staying, as it is shown upon Hana's arrival (16:10), makes the one book even more special. Hana transforms other books into stair steps to make it easier to go upstairs, into Almásy’s room. Before asking him about "his" own book, Hana explains it to him: "I was preparing the stairs. I found a library, and the books were very useful” (18:50). The camera then zooms to show Almásy’s book lying 
on a marble counter in the room: a brown leather-covered, bulky, old book. In the next scene featuring it, scarred Almásy reaches for the book on his nightstand, looks significantly at it, then turns its pages, exhibiting colorful cuttings placed between them. He drops it, and, from a high-angle shot, the camera shows the cuttings scattering on the floor (21:00) - it is when viewers realize that those contents are probably essential to the story being told. In the many occasions the book is displayed during the film, the detached contents are always there. It is never only Herodotus' book, neither it is ever only "a" book.

The book also becomes Katherine's diary in her dying days in the cave. Before leaving her to search for help, Almásy gives it to her and says: "Good read" (2:13:15). We do not see her reading, though, but writing. Before dying, Almásy asks Hana to read it to him (2:30:44). Images of Katherine and Hana and voiceovers with both their voices are edited together to read what she wrote: "My darling, I'm waiting for you. How long is a day in the dark? Or a week?" (2:31:20). Almásy dies while hearing Hana reading Katherine's words registered in his book. At the end of the film, we see Hana running back into the room now empty - to take Almásy's book with her when she leaves the villa and goes home. Even after his death, the book will prevail.

\section{Atonement and the writing fetish}

A criminal misunderstanding is at the center of McEwan's Atonement. Thirteen-year-old Briony Tallis imagines that her sister Cecilia is being harassed by Robbie Turner, the son of a servant at their English estate. This leads Briony to wrongfully accuse Robbie of raping her cousin. Robbie is taken to prison, then later to Dunkirk, and his relationship with Cecilia is doomed forever. Briony becomes a novelist and tries to atone for her error by rewriting the lovers' fate.

As "epistolary fiction", Atonement truly attends the requisite of being "full of meta-commentary on the writing, reading, or finding of letters, on the excitement upon the arrival of a letter or the disappointment upon not receiving a letter, on the opening of letters, the first reaction upon reading a letter, attempts at interpreting a letter, and so on and so forth" (Schuh 2018, 73). Letters allow for first-person insight in a multiperspective narrative (Hallet 2018, 131), holding events and characters together and reminding us of the "literariness" of the novel (Ellam 2009, 46). In McEwan's work, letters "act at the same time both as a medium of the narrative and an element in the plot" (Genette 1983, 217); such narrative technique, as it will be shown in the analysis that follows, is mirrored in the film adaptation.

Because of the presence of letters, in Wright's film, the voiceover technique is largely adopted, permitting characters to recite messages on the soundtrack while images show them doing something else, which can be seen as a cinematic advantage: "The cinema has two physical tracks - the image track and the soundtrack - so one easily imagines that film can simultaneously express what is seen - through the image track - and what is thought - through voice-over" 
(Jost 2004, 73). Even though the use of voiceover is often criticized as too much of a "literary technique" (Kozloff 52) that may jeopardize the dramatic potency of a film, Atonement does not seem to suffer such risk. This is at least partly thanks to the fact that, as it also happens in The English Patient, the director and his creative team adapted whole dialogues and descriptions of the source novel into sequences of rich, captivating images, thus balancing the wordy use of voiceover.

The use of voiceover can also balance the narrative of a film in other ways. In its second act, Atonement takes part in the war film tradition, focusing on Robbie (James McAvoy) and other soldiers in France. Cecilia (Keira Knightley) invades an all-male environment with her letters. The female voice is said to give "a rare precedence and a presence" of women in the war: "The epistolary female character in war films is a complex correspondent who is either yearned for, revered, feared, or despised" (Walsh 2005, 306). In this instance, Cecilia is clearly revered. This is one of the coincidences that bring The English Patient and Atonement together: both prioritize a love story - this time between Robbie and Cecilia - that takes less space in their source novels. In the case of Atonement, this has led some critics to suggest that the "adaptation falls into romance or melodrama" (Geraghty 363).

Writing and exchanging letters are imperative elements in Wright's cinematic narrative. Travers (2007, para. 1) says that the film is "literary in the best possible sense: it's obsessed with the power of words". The opening credits are predicative of what it is to come: we hear a typewriter being loaded and then typing the title of the film. It is as if it announced its intimate bond with literature. Soon we see that the typing is coming from the workings of a young girl at her desk - by her side, there is a pile of pages topped by a hand-embellished cover of "The Trials of Arabella, by Briony Tallis," which we, spectators, read under the light of a sunbeam coming from the window.

As Briony (Saoirse Ronan) then walks through the house, we still hear typing on the soundtrack, as if her footsteps were keystrokes (1:49). Her first conversation with Robbie is about the play she wrote; he asks her if he can read it (3:00). Next, we first see Cecilia lying on her stomach in the garden as she reads a book; the camera hovers over her, highlighting the curves of her body dressed in fluid light fabric, thus portraying reading as a sensual, languid activity. Her first interaction with Robbie also addresses reading, as he asks her if she is enjoying her book: "No, not really", she answers. And she continues: "I prefer Fielding any day. Much more passionate" (10:11).

After this prologue, Briony misinterprets what she sees from afar, which is a crucial event in the building of her unatonable error. Shot laterally from a shoulder-level angle, the girl, who is now in her playroom inside the house, approaches the window with an inquisitive look on her face. The camera cuts to a close-up of a bee buzzing on the window glass plate, an annoying presence that announces trouble. The camera then cuts back to the girl's distressed face, now with an eye-level shot. From a long angle, assuming Briony's point of view, the camera shows us what she sees: Robbie watching while her sister undresses 
and jumps into the garden fountain. Frustrated by this sight, she then escapes to hide among the luscious greenery of the garden and writes compulsively (20:50). Here, writing is portrayed as cathartic, therapeutic. Briony's mixing of reality and fiction, her propensity to fantasize about people in her life as if they were characters, is linked with her urge to write, which "signals ironically the dangers of literary imagination" (Ellam 32). As she writes, we hear her story - of princesses and knights - on the voiceover, and we are still hearing it when the image cuts to Robbie. She recites "He [a character of her imagination] was the most dangerous man in the world" (21:09) while the camera frames Robbie's back typing at his desk, reinforcing Briony's current impression of him. In the book, we know the origin of his typewriter, which was "given to him on his twenty-first by Jack Tallis [Briony and Cecilia's father] at a lunchtime party held in the library" (McEwan 77).

The following sequence is arguably the most powerful one in Wright's film, and a demonstration of how written words can be cleverly used in cinema. Robbie types and tosses several versions of an apologizing note to Cecilia (21:22). He puts an opera record on the player. The editing of the following scenes combines sounds - the aria being played, the typewriting - and images of both Robbie in his writing endeavor and Cecilia getting ready for dinner in the main house. They both smoke and are veiled and unveiled by an oversaturated sunlight. Finally, a close-up allows us to read a new version on the porous paper in the typewriter: "In my dreams, I kiss your cunt, your sweet wet cunt" (23:56). Robbie bursts out in laughter. He folds the note, puts it on the desk and handwrites another one, asking for Cecilia's forgiveness. We hear both the fountain pen scratching on the paper and his voiceover "Will you forgive me?" while we watch her fixing her hair - an example of the cinematic ability to "show someone or something and at the same time express something completely different through the voice" (Jost 73). Once Robbie finishes handwriting the note, the camera focuses on the pen rolling free on the desk (24:48), an indication of his lack of control. A little later, we watch him asking Briony to deliver it - he offers her the cream-colored envelope against the clarity of the afternoon outside.

The whole sequence of gestures is as visual as cinema can be. As Travers (para. 5) puts it, "Wright and Christopher Hampton, whose script is a model of page-to-screen adaptation, show extraordinary skill in building this hothouse of carnal tension". In this first part of the film, "the most powerful words are unspoken and appear as writing, typed on the page, and as cinema, in huge closeups", with the two media combining together "to convey the power of the word" (Geraghty 366). The written words are there for spectators to read them because Robbie does not recite in voiceover the "obscene" note, only the apologetic one. It is interesting to notice here that, although "many films reveal the contents of a plot-turning letter or telegram by laying in the voice of author or recipient reading it out loud" (Kozloff 5), in this case, the opposite takes place: the plotturning note is the one left out of voiceovers. The word/image hybrid requires us to infer the repressed attraction between Robbie and Cecilia, and to predict 
the disastrous outcome; while Briony runs with the note, the camera shows, in a rapid movement, that Robbie, in a Freudian slip (Ellam 55), delivered the wrong one. Opera and frenetic typewriting sounds combine in the soundtrack when the sequence of Briony running is cut so that the camera can zoom toward Robbie's desk from a slightly high angle. Under the oversaturated, white-colored light, it reveals that the handwritten note is still lying there. The film cuts back to Briony, who's standing in the house's main hall as she rips the envelope open and hungrily reads the indecent note - the camera frames her on a low-angle shot, partially through the paper below her face. Next, the apotheosis: the word "cunt" is "rewritten letter by letter" (Geraghty 367) for us, viewers, each stroke booming on the soundtrack, then silence (28:20).

More writing-related elements participate in the turmoil that unfolds in the sequence. Cecilia and Robbie have sex in the house's library, pressed against book shelves, and are caught by the already disgusted Briony, who later finds a new note on her bed - this time, her twin cousins are declaring that they would run away. In a study about this specific note as an instrumental device to the unfolding of the plot, Tollance $(2018,1)$ remarks that "the words that appear in big, illformed letters on the screen also give a greater resonance to the uncertainty that surrounds the act of writing."

The note does advance the plot: a search party is organized to look for the twins, and it is during the search that Briony sees Lola (Juno Temple) being raped. She does not know by whom, but concludes that it must be Robbie and gives a false statement to the police. While she frantically looks for the earlier note from Robbie to Cecilia as yet another proof that he is a "sex maniac," we hear typewriting sounds - mostly like "the staccato rhythm of footsteps" (Tollance 5). When she finds the paper to be delivered to the police as evidence, the camera frames the page in her hands from a slightly high-angle close-up shot, so that we, viewers, can read for the first time the second sentence of Robbie's writing: "In my thoughts I make love to you all day long" (45:59). This is a smart detour from the novel, in which we read the whole note at once (McEwan 80). As this second sentence gives the note a sweeter, more romantic tone, its late reveal increases our consternation as viewers when Robbie is arrested under Briony's gaze, watching from the window, while typewriting noises grow louder on the soundtrack.

As the story continues, the reading/writing fetish moves to other objects, particularly to a postcard Cecilia hands to Robbie before he leaves for war. The postcard shows a beach house, Robbie and Cecilia's forever lost place of happiness, and acts as a cover to a pack of letters presumably sent to him by her - a pile of voluminous writings which is carried everywhere by him, as Almásy's book in Minghella's The English Patient. In one of the moments Robbie looks at the postcard, he imagines his slip being corrected: retrieving the note from Briony's hands, and the word "cunt" being unwritten on paper (1:17:16). When Robbie dies, his soldier friend takes the pack of letters with him, in a gesture similar to Hana's with Almásy's book: people are gone, but their writings are left behind to keep them somehow alive. 
While the fetishizing of the act of writing suggests heat and repressed desire in the first part of the film, with type bars striking against sunlight-bathed pages, in the second part, an older Briony (Romola Garai) keeps her typewriter in a small wardrobe and types at night, in a dark and damp attic at the hospital where she works as a nurse during the war. The insistent sound of keystrokes still follows her; we hear it while she walks in the corridors of the hospital and on the train, after a visit she pays to Robbie and Cecilia (1:46:01) - a fictional visit to a fictionally united couple, as viewers will learn later in the film. The fetishizing of writing and correspondence clashes with Briony's physical effort to come clean by literally washing chamber pots, wiping floors, and severely scrubbing her hands her physical exertion, however, does not change her literary nature, as the sound of typewriting constantly reminds us.

In the future, when we see Briony as a seventy-seven-year-old woman (Vanessa Redgrave) being interviewed on television, we learn that literature was indeed her call and that she has published twenty novels before finally trying to atone with her last work for what she did as a young girl. The scene recreates the impact of the twist in McEwan's novel by framing the actress' face in an emotional close-up while she monologues about her attempt to atone through the writing of fiction - she reveals that Robbie and Cecilia were never truly reunited, only in her novel. Her writing was a substitute for something unattainable.

The film's final note is bittersweet. For almost two hours, Atonement seduces us with its fetishizing of the written word only to dismantle this seduction in the last sequences; it is as if it reminded us that the fetish is only a stand in, not the real thing. As alluring as the writing of fiction and the exchanging of letters can be, they cannot fulfill what it is truly lacking. Briony eventually explains that she is now dying of vascular dementia, "a series of tiny strokes" (1:47:57), like the typewriter keystrokes that accompany her everywhere during the film.

\section{Discussion}

The English Patient and Atonement share key coincidences. They have the Second World War as background and tell the story of doomed love affairs. They also contain themes, scenes, and various elements related to reading and writing. Both were commercially successful as literature and as cinema - proudly marketed as "based on" the already acclaimed novels (about Atonement's marketing as an adaptation, see Geraghty), which may answer the question: "But why would a film want to be seen as an adaptation?" (Hutcheon 2) - perhaps it is because it intends to participate in the source material's success and to increase it, in a winwin process. As Ellis $(1982,3)$ argues: "The adaptation trades upon the memory of the novel, a memory that can derive from an actual reading, or, as is more likely with a classic of literature, a generally circulated cultural memory." This means that adaptations like the ones discussed here, executed only a few years after the publishing of the novels, may also act as substitutes for their reading, or encourage spectators to go back and read them. 
Both films prioritize love above sociopolitical commentary; the horrors of war are diminished next to the tragedy of unachievable idyll (about The English Patient, see Laing 55-56; Hutcheon 8). As period pieces, they are carefully conceived. Beautiful effects created by set and costume design, as much as cinematography work, were recognized by various prizes. Both also emphasize their relation to literature at the same time that they exhibit an amalgam of other arts and crafts. In this sense, the notion that film adaptations could be a transfer from telling to showing, or even "translations in the form of intersemiotic transpositions from one sign (for example, words) to another (for example, images)" (Hutcheon 12), does not comprehend the complexity of transforming a novel into a composition of many arts reunited on screen. In The English Patient, Hana plays the piano, and Kip (Naveen Andrews) takes her to see the frescoes of an Arezzo church - as the camera scans the walls, we can marvel at them with her; Almásy sews, and Katherine buys tapestry. They all sing and dance at some point. Katherine even watches a film about the war. Atonement, for its part, "draws heavily on writing but it also references a wide variety of other media from opera to newsreels and on a number of media transmitters such as the typewriter and the gramophone" (Geraghty 365).

In fact, the use of typewriters in Atonement deserves an observation. More than featuring typewriters, it also fetishizes them - visually and audibly. Curiously enough, in contemporary motion pictures, typewriters have been turned into a symbol of the old charms that have been lost in a computer era. There is something about a typewriter's physicality, about the sounds it makes, and the gestures used to make them. In cinema, typewriters generally help to portray a non-compelling act, that is, the act of writing: "For this reason the very tools of writing often stand in for the larger (and boring) composition process, and thereby achieve iconic status. In the broad history of cinema, the emblem (and, perhaps, the fetish object) in question has been the typewriter" (Fischer 2013, 20).

At points, both films require viewers to be readers. In The English Patient, we read Almásy's notes about Katherine while she does. In Atonement, the reading of Robbie's note is, of course, essential to the understanding of the plot, as it is the reading of the address on an envelope that Cecilia puts in the mailbox, which tells us that Robbie is in France. The titles of Briony's literary works - the play The Trials of Arabella and later the novella The Figures by the Fountain - are also shown, not spoken.

It is their fetishizing of the written word that brings these films even closer together. By showing characters reciting, reading, and writing, in addition to objects related to these actions, The English Patient and Atonement do not tell - at least not in the pejorative sense of the screenplay writing axiom "show, don't tell" (Noble 1991) - but, instead, they use written "telling" as a means of advancing the plot and deepening the possibilities of interpretation, thus magnifying the association with their literary origin. This is a risky aesthetical choice, since it is not uncommon for critics to accuse such devices of being a "subordination" to the source literary text, especially in the case of canonized 
texts (Somigli 1998, 294-295). The use of the written word, or any word for that matter, however, is not uncinematic; on the contrary, it has always been there, first in the form of intertitles in silent films, and later assuming other various roles. As Elliott $(2004,2)$ states, "films abound in words - in sound dialogue, intertitles, subtitles, voice-over narration, credits, and words on sets and props - and written texts form the basis of most films".

The fetishizing processes in The English Patient and Atonement slightly differ from each other. Almásy's book works as a magical centerpiece for practically all relationships in The English Patient, from beginning to end, guarding memories and images, being used as a journal by more than one character, and surviving windstorm, fire, and the death of its owner. The book is an example of "the human ability to project value onto a material object" and to "interpret the object as the autonomous source of that value" (Mulvey Fetishism 217). In Atonement, the fetishized elements - languid reading in the garden, sensual notes typewritten on cream-colored paper - change when the characters' repressed desire turns into frustrated desire. The focus is then channelized to the simple image of a postcard, symbol of everything that was lost, but maintaining the otherworldly power of exchanging letters and of writing; this is such a great power that it deceives us, viewers, into believing in Briony's fanciful recount of events that never took place. The sound of keystrokes is always there, working as a reminder of her imaginative nature as a writer - and of the fatal error provoked by it.

The fetishized objects are worshiped by the camera, whose work is crucial to their fetish status. In The English Patient, the framing of the voluminous old book and its contents, be it in people's hands or on Almásy's nightstand, is always charged with meaning. What secrets does it keep? It is as if we wanted to be able to turn its pages as well, to look at each note, cutting, painting, and photograph kept inside. Reading Herodotus is not going to solve our curiosity, because Almásy's book is more than that - it is fetishized because it is "more," because no matter how many times it is shown, we cannot access it. In Atonement, writing itself, eroticized by the camera in the apotheotic sequence of Robbie's note, is a promise of everything: establishing relationships and destroying them. By framing the piece of writing, the camera shares a secret with the viewers, turning us into the voyeurs that cameras naturally are. As with Almásy's book, we are seduced to look at it.

\section{Final considerations}

The English Patient and Atonement invite film viewers to accompany the camera on its voyeurism and to become curious readers. In displaying such devotion to the written word, in so many ways, these films seem to remind us constantly of something that has been partially lost in the process of adaptation - the "written words" on which they are based - honoring, in this way, their source novels. It is not a question of the movies not being able to unlink themselves from their "birthplaces," because both films are cinematic creations 
that stand on their own. But they do not wish to do so; their adaptation status is not only firmly displayed on the credits, it also reverberates through the loving attitude toward reading and writing displayed by characters, and through a fetishizing camera that persistently focuses on books, typewriters, papers, parchment, and other things related to the written word. By giving these objects a special treatment, a "glittering" status (Mulvey Fetishism 6), cinema not only suggests fetish, but performs it.

Both films use surrogate objects (Apter 4) to stand in for the satisfaction that is never accomplished by their characters and, therefore, neither by the audience, who must deal with the emptiness that comes with unrealized love stories. Minghella and Wright, as well as their respective teams, were able to re-create on screen the sensation of "something perceived as missing", as Mulvey ("Some Thoughts" 8) describes when explaining Freud's conception of fetishism. In their films, the absent element - satisfaction - is substituted by a myriad of prosaic items overvalued by lightning, camera angles, and soundtrack. Characters also act obsessively around these objects, which only contributes to their feverous aspect: the touching of a book provokes overwhelming emotions; the exchange of letters replaces actual physical contact; the typewriter's staccato alludes to the rhythmic vibration of the pulse.

Almásy's book in The English Patient is an example of a fetishized element around which characters create bonds and display emotional reactions that have nothing to do with the reading of Herodotus. This is as odd as it is understandable, reflecting the duplicity suggested by psychoanalysis: human psyche is divided into what can be known and what is secret (Mulvey Fetishism 76). As a common and harmless object, the book can be carried around by its owner, Almásy, and by other characters; the repressed desires it replaces, however, are kept hidden. This produces a tension, as we, spectators, know that the book means more to the characters than a common book would and wish this "more" to come to the surface.

However, the Freudian slip of the indecent note's delivery in Atonement illustrates what can happen when a repressed secret comes to light - as none of the characters seems to be prepared to deal with it, the only alternative is to repress it again, which is represented by the imprisonment of the note's author and the condemnation of an otherwise promising love story.

Future investigations may search for more possible associations between reading and writing as fetishized elements in The English Patient and Atonement, as well as in other motion pictures and the novels they adapt. Written words fetishized in cinema certainly deserve further reflection.

Notes

1. Written and directed by Anthony Minghella (Oscar of Best Director). A production by Miramax. Produced by Saul Zaentz (Oscar of Best Picture); cinematography by John Seale (Oscar of Best Cinematography; music by Gabriel Yared (Oscar of Best Music, Original Dramatic Score); editing by Walter Murch (Oscar of Best Editing and of Best Sound); production design by Stuart Craig and Stephenie 
McMillan (Oscar of Best Art Direction/Set Decoration); costume design by Ann Roth (Oscar of Best Costume Design); art direction by Aurelio Crugnola. Juliette Binoche won the Oscar of Best Actress in a Supporting Role.

2. Produced by Universal Studios. Main producers: Tim Bevan, Eric Fellner, and Paul Webster. Cinematography by Seamus McGarvey; music by Dario Marianelli (awarded the Oscar 2008 of Best Achievement in Music Written for Motion Pictures, Original Score); editing by Paul Tothill; production design by Sarah Greenwood; costume design by Jacqueline Duran; art direction by Ian Bailie. Saoirse Ronan (young Briony) was nominated to the Oscar of Best Actress in a Supporting Role.

3. Lázló Almásy was a real Hungarian aviator. Among other sources, his story is told by John Bierman in the biography The Secret Life of Laslo Almasy: The Real English Patient (2004). Laing says that "historians questioned the film's representation and possible romanticization of an actual and somewhat problematic historical figure. The real Count Laszlo de Almásy's prowess as an explorer was less in contention than the question of his actual allegiance to the German forces during World War II and his apparent homosexuality" (54).

\section{References}

Apter, Emily. Feminizing the Fetish: Psychoanalysis and Narrative Obsession in Turnof-the-Century France. Cornell University Press, 1991.

Atonement. Directed by Joe Wright, performances by Saoirse Ronan, Keira Knightley, James McAvoy, and Romola Garai, Universal Pictures, 2007.

Bolland, John. Michael Ondaatjes The English Patient: a reader's guide. Continuum, 2002.

Cahir, Linda Costanzo. Literature into Film: theory and practical approaches. McFarland \& Company, 2006.

Bradshaw, Peter. "Atonement." The Guardian, 7 September 2007. https://www. theguardian.com/film/2007/sep/07/romance.keiraknightley. Accessed 10 June 2020.

Ebert, Roger. “The English Patient." RogerEbert.com, 22 November 1996, https:// www.rogerebert.com/reviews/the-english-patient-1996. Accessed 12 June 2020.

Ellam, Julie. Ian McEwan's Atonement: a reader's guide. Continuum, 2009.

Elleström, Lars. "Adaptation and intermediality." The Oxford Handbook of Adaptation Studies, edited by Thomas Leitch. Oxford University Press, 2017. pp. 509-526.

Elley, Derek. "Atonement." Variety, 29 Aug. 2007, https://variety.com/2007/film/ awards/atonement-6-1200556868/. Accessed 12 June 2020.

Elliott, Kamilla. "Novels, films, and the word/image wars." A companion to literature and film, edited by Robert Stam and Alessandra Raengo. Blackwell, 2004. pp. 1-22.

Ellis, John. The Literary Adaptation, Screen, v. 23, n. 1, May/June 1982, pp. 3-5.

Fischer, Lucy. Body Double: the author incarnate in the cinema. Rutgers University Press, 2013.

Freud, Sigmund. Sexuality and the Psychology of Love. Simon \& Schuster, 1997, pp. 204-209.

Genette, Gérard. Narrative discourse: an essay in method. Translated by Jane E. Lewin. Cornell University Press, 1983. 
Geraghty, Christine. "Foregrounding the media: Atonement (2007) as an adaptation." A Companion to Literature, Film, and Adaptation, edited by Deborah Cartmell. Wiley-Blackwell, 2012. pp. 359-373.

Gleiberman, Owen. “The English Patient': EW review." Entertainment, 22 November $1996 . \quad$ https://ew.com/article/1996/11/22/movie-review-english-patient/. Accessed 13 June 2020.

Hallet, Wolfgang. "Epistolary forms as semiotic and generic modes in the multimodal novel." The Epistolary Renaissance: a critical approach to contemporary letter narratives in Anglophone fiction, edited by Maria Löschnigg and Rebekka Schuh. De Gruyter, 2018. p. 125-142.

Hutcheon, Linda [with Siobhan O'Flynn]. A Theory of Adaptation. Second Edition. Routledge, 2013. eBook.

Jost, François. “The look: from film to novel - an essay in comparative narratology”. A Companion to Literature and Film, edited by Robert Stam and Alessandra Raengo. Blackwell, 2004. pp. 71-80.

Kozloff, Sarah. Invisible Storytellers: Voice-Over Narration in American Fiction Film. University of California Press, 1988.

Laing, Heather. Gabriel Yasred's The English Patient: a film score guide. Scarecrow Press, 2007.

McEwan, Ian. Atonement. Doubleday, 2002.

Moses, Gavriel. "The Bible as Cultural Object(s) in Cinema”. A companion to literature and film, edited by Robert Stam and Alessandra Raengo. Blackwell, 2004. pp. 399422.

Mulvey, Laura. Fetishism and Curiosity. Indiana University Press, 1996.

Mulvey, Laura. "Some Thoughts on Theories of Fetishism in the Context of Contemporary Culture." October, vol. 65, 1993, pp. 3-20.

Noble, William. Show Don't Tell: a writer's guide. The Write Thought, 1991.

Ondaatje, Michael. The English Patient. Bloomsbury, 2004.

Schuh, Rebekka. "Enveloped in epistolary illusion: the aesthetics of reading and writing letters in selected short stories by Alice Munro." The Epistolary Renaissance: a critical approach to contemporary letter narratives in Anglophone fiction, edited by Maria Löschnigg and Rebekka Schuh. De Gruyter, 2018. pp. 73-90.

Simon, Jeff. "Not well "The English Patient" suffers from some fatal flaws." The Buffalo News, 22 November 1996. https://buffalonews.com/1996/11/21/not-well-theenglish-patient-suffers-from-some-fatal-flaws/. Accessed 14 June 2020.

Somigli, Luca. "The Superhero with a Thousand Faces: Visual Narratives on Film and Paper". Play It Again, Sam: retakes and remakes, edited by Andrew Horton and Stuart Y. McDougal. University of California Press, 1998. pp. 279-294.

The English Patient. Directed by Anthony Minghella, performances by Juliette Binoche, Ralph Fiennes, and Kristin Scott-Thomas, Miramax, 1996.

Tollance, Pascale. “'To everyone,' 'To whom it may concern': the letter for which no one can answer in Atonement (Ian McEwan and Joe Wright)." Études britanniques contemporaines, 55, 2018, https://journals.openedition.org/ebc/5529. Accessed 12 June 2020.

Thomas, Brownen. '“Piecing together a mirage:' adapting The English Patient for the screen." From Page to Screen: Adaptations of the Classic Novel, edited by Robert Giddings and Erica Sheen. Manchester University Press, 2000. pp. 197-232. 
Travers, Peter. "Atonement." Rolling Stone, 14 December 2007. https://www. rollingstone.com/movies/movie-reviews/atonement-252218/. Accessed 11 June 2020.

Walsh, Susie. "Friendly fire: epistolary voice-over in Terrence Malick's 'The Thin Red Line." Literature/Film Quarterly vol. 33, n. 4, 2005, pp. 306-12.

Wootton, Sarah. "'Here then is a maze to begin, be in': Michael Ondaatje's Byronic Inheritance." Romantic Presences in the Twentieth Century, edited by Mark Sandy. Routledge, 2016. pp. 163-174.

Recebido em: 26/07/2020

Aceito em: 24/11/2020 